\title{
Expression, Purification, and Characterisation of Dehydroquinate Synthase from Pyrococcus furiosus
}

\author{
Leonardo Negron, ${ }^{1}$ Mark L. Patchett, ${ }^{2}$ and Emily J. Parker ${ }^{3}$ \\ ${ }^{1}$ Institute of Fundamental Sciences, Massey University, Palmerston North 4442, New Zealand \\ ${ }^{2}$ Institute of Molecular Biosciences, Massey University, Palmerston North 4442, New Zealand \\ ${ }^{3}$ Department of Chemistry, Biomolecular Interaction Centre, University of Canterbury, Private Bag 4800, \\ Christchurch 8140, New Zealand
}

Correspondence should be addressed to Emily J. Parker, emily.parker@canterbury.ac.nz

Received 6 October 2010; Revised 28 January 2011; Accepted 8 February 2011

Academic Editor: Vasu D. Appanna

Copyright (๑) 2011 Leonardo Negron et al. This is an open access article distributed under the Creative Commons Attribution License, which permits unrestricted use, distribution, and reproduction in any medium, provided the original work is properly cited.

Dehydroquinate synthase (DHQS) catalyses the second step of the shikimate pathway to aromatic compounds. DHQS from the archaeal hyperthermophile Pyrococcus furiosus was insoluble when expressed in Escherichia coli but was partially solubilised when $\mathrm{KCl}$ was included in the cell lysis buffer. A purification procedure was developed, involving lysis by sonication at $30^{\circ} \mathrm{C}$ followed by a heat treatment at $70^{\circ} \mathrm{C}$ and anion exchange chromatography. Purified recombinant $P$. furiosus DHQS is a dimer with a subunit $\mathrm{Mr}$ of 37,397 (determined by electrospray ionisation mass spectrometry) and is active over broad $\mathrm{pH}$ and temperature ranges. The kinetic parameters are $K_{M}$ (3-deoxy-D-arabino-heptulosonate 7-phosphate) $3.7 \mu \mathrm{M}$ and $k_{\text {cat }} 3.0 \mathrm{sec}^{-1}$ at $60^{\circ} \mathrm{C}$ and $\mathrm{pH} 6.8$. EDTA inactivates the enzyme, and enzyme activity is restored by several divalent metal ions including (in order of decreasing effectiveness) $\mathrm{Cd}^{2+}, \mathrm{Co}^{2+}, \mathrm{Zn}^{2+}$, and $\mathrm{Mn}^{2+}$. High activity of a DHQS in the presence of $\mathrm{Cd}^{2+}$ has not been reported for enzymes from other sources, and may be related to the bioavailability of $\mathrm{Cd}^{2+}$ for $P$. furiosus. This study is the first biochemical characterisation of a DHQS from a thermophilic source. Furthermore, the characterisation of this hyperthermophilic enzyme was carried out at elevated temperatures using an enzyme-coupled assay.

\section{Introduction}

The enzyme dehydroquinate synthase (DHQS, EC 4.2.3.4) catalyses the transformation of the seven-carbon sugar 3deoxy-D-arabino-heptulosonate 7-phosphate (DAH7P) into the carbocycle dehydroquinate (DHQ). This reaction is the second step of the shikimate pathway. This biosynthetic pathway is responsible for producing the precursors of aromatic amino acids (phenylalanine, tyrosine, and tryptophan) that are vital for the homeostasis of various plants, fungi, and prokaryotes [1]. The absence of the shikimate pathway in humans makes the enzymes of this pathway potential targets for new antibacterial and antifungal agents $[2,3]$.

DHQS is monofunctional in most bacteria; however, in some organisms, it is part of a larger protein known as AROM complex [4]. The AROM complex is a pentafunctional polypeptide containing enzymes that catalyse steps two, three, four, and five of the shikimate pathway [5]. Aspergillus nidulans and Neurospora crassa DHQS enzymes exist in nature as part of the AROM protein [6]. Similarly, Bacillus subtilis DHQS is part of a trifunctional enzyme complex that also contains chorismate synthase and NADPH flavin reductase [7]. More recently, DHQS enzymes that form part of multifunctional complexes have been expressed and isolated as recombinant monofunctional proteins $[6,8]$.

DHQS has been an enzyme of much interest due to the complexity and variety of reactions that it catalyses despite its relatively small size $[9,10]$. Furthermore, DHQS activity has been shown to be required for pathogen virulence [11]. Examples of DHQSs that have been characterised include those from Escherichia coli, Corynebacterium glutamicum, Thermus thermophilus, Helicobacter pylori, Bacillus subtilis, A. nidulans, N. crassa, Phaseolus aureus (mung bean), Sorghum sp., and Pisum sativum $[6-8,12-16]$. Currently, there are five 
DHQS crystal structures available in the RCSB protein data bank; these are from A. nidulans (1DQS), T. thermophilus (1UJN), H. pylori (3CLH), Staphylococcus aureus (1XAG), and Vibrio cholerae (3OKF) $[10,12,13,17]$. Preliminary diffraction data has also been recorded for the DHQS from Xanthomonas oryzae pv. [18]. Of the four DHQSs for which crystal structures are available, those from $A$. nidulans and T. thermophilus assemble as homodimers, whereas $S$. aureus DHQS is monomeric $[10,12,17]$. In contrast, the DHQS from $H$. pylori assembles as a hexamer composed of three dimers [13].

All DHQS enzymes require a divalent metal ion and $\mathrm{NAD}^{+}$for activity and convert DAH7P to DHQ by way of a five-step reaction process. This reaction mechanism involves an oxidation, elimination of phosphate, reduction, ring opening, and an aldol reaction step [19-22].

Comparisons of enzyme kinetic parameters for these enzymes are problematic since different methods have been used to measure activity. The two most common are (i) the measurement of inorganic phosphate $\left(P_{i}\right)$ release and (ii) a coupled enzyme assay whereby DHQ is converted to dehydroshikimate (DHS) and the latter measured spectrophotometrically $[23,24]$. The measurement of $P_{i}$ release has been found to be relatively insensitive and results in the inaccurate determination of kinetic parameters [19]. For example, the E. coli DHQS $K_{M}$ for DAH7P determined by monitoring $P_{i}$ release was $18 \mu \mathrm{M}$, and that determined by using the DHS-coupled assay was $4 \mu \mathrm{M}[25,26]$.

$P$. furiosus is an anaerobic, hyperthermophilic archaeon originally isolated from geothermally heated marine sediments and has an optimal growth temperature of $100^{\circ} \mathrm{C}$ [27]. In this study, we report the expression, purification, and characterisation of $P$. furiosus recombinant DHQS and a comparison of its properties with the enzyme from the mesophile E. coli. This is the first report of the biochemical properties of an archaeal DHQS, and also the first characterisation of DHQS from a hyperthermophilic source, necessitating the development of a coupled assay that functions at elevated temperatures up to $80^{\circ} \mathrm{C}$.

\section{Material and Methods}

2.1. Pyrococcus furiosus DHQS (PfuDHQS) Cloning. Standard PCR methodologies using P. furiosus DSM 3638 purified genomic DNA as template, primers $P f u D H Q S f w d$ (5'-AGGTTCTCATATGGAAGGGATAATTTTTGGAGAT) and $P f u$ DHQSrev (5'-CCGGGATCCTTAGGCATTTTTAGCTTCCT), and $P f u$ Turbo DNA polymerase (Stratagene) were employed to amplify the P. furiosus DHQS gene (locus tag PF1691) and to introduce NdeI and BamHI recognition sites (underlined) into the $1027 \mathrm{bp} \mathrm{PCR} \mathrm{product.}$ The PCR product was purified directly (high pure PCR product purification kit, Roche), digested with $N d e I$ and BamHI, ethanol precipitated, and ligated to pT7-7 previously restricted with the same endonucleases [28]. The ligation reaction was used to transform chemically competent $E$. coli XL1-Blue cells. Plasmid miniprep DNA was isolated from ampicillin-resistant colonies and digested with $N d e I$ and
BamHI, followed by agarose gel electrophoresis, to identify recombinant plasmids. One putative pT7-PfuDHQS expression plasmid was sequenced on both strands to confirm the expected DNA sequence and was then transformed into chemically competent E. coli Rosetta (DE3) cells (Novagen). Transformants of this strain were routinely grown at $37^{\circ} \mathrm{C}$ with vigourous shaking in Luria Bertani (LB) medium (Gibco) supplemented with $100 \mu \mathrm{g} / \mathrm{mL}$ ampicillin (Sigma) and $34 \mu \mathrm{g} / \mathrm{mL}$ chloramphenicol (Sigma).

2.2. Pyrococcus furiosus 3-Dehydroquinase (PfuDHQase) Cloning. Standard PCR methodologies using P. furiosus DSM 3638 purified genomic DNA as template, primers $P f u$ DHQasefwd (5'-GAAGCTACATATGCCTAAATTGGCCGGAGTTA) and PfuDHQaserev (5'TCCGGATCCATTATTTTGTCTCACCTAGCAATT), and $P f u$ Turbo DNA polymerase were employed to amplify the $P$. furiosus 3-dehydroquinase (EC 4.2.1.10) gene (locus tag PF1692) and to introduce NdeI and BamHI recognition sites (underlined) into the $674 \mathrm{bp}$ PCR product. The PCR product was purified directly, digested with NdeI and BamHI, ethanol precipitated, and ligated into pT77 previously restricted with the same endonucleases. The ligation reaction was used to transform chemically competent E. coli XL1-Blue cells. Plasmid miniprep DNA was isolated from ampicillin-resistant colonies and digested with NdeI and BamHI, followed by agarose gel electrophoresis, to identify recombinant plasmids. One putative pT7-PfuDHQase plasmid was sequenced on both strands to confirm the expected DNA sequence and was then transformed into chemically competent E. coli Rosetta (DE3) cells. Transformants of this strain were routinely grown at $37^{\circ} \mathrm{C}$ with vigourous shaking in LB medium supplemented with $100 \mu \mathrm{g} / \mathrm{mL}$ ampicillin and $34 \mu \mathrm{g} / \mathrm{mL}$ chloramphenicol.

2.3. Purification of E. coli DHQS (EcoDHQS). E. coli RB791 cells, transformed with the plasmid encoding the E. coli DHQS gene, obtained from Professor John R. Coggins (University of Glasgow), were grown overnight at $37^{\circ} \mathrm{C}$ in LB medium supplemented with ampicillin $(100 \mu \mathrm{g} / \mathrm{mL})$. Overexpressed EcoDHQS was purified using a modification of the method published by Frost and coworkers [8]. Soluble protein from crude lysate was subjected to ammonium sulfate precipitation at $4^{\circ} \mathrm{C}$. Fractions between 35 and $55 \%$ ammonium sulfate were pooled, desalted on a size exclusion column, concentrated and subjected to anion exchange chromatography using Source $\mathrm{Q}$ resin (Amersham Biosciences) (Buffer A: $10 \mathrm{mM} \beta$-glycerophosphate (Sigma), $\mathrm{pH}$ 6.6; Buffer B: $10 \mathrm{mM} \beta$-glycerophosphate with $1 \mathrm{M}$ $\mathrm{NaCl}$ (Sigma), pH 6.6). Fractions containing purified DHQS (eluted at $\sim 90 \mathrm{mM} \mathrm{NaCl}$ ) were pooled and concentrated.

2.4. Purification of E. coli DHQase (EcoDHQase). E. coli AB2848/pKD201 cells containing the E. coli DHQase gene were grown overnight at $37^{\circ} \mathrm{C}$ in $\mathrm{LB}$ medium supplemented with ampicillin $(100 \mu \mathrm{g} / \mathrm{mL})$. Overexpressed EcoDHQase was purified by anion exchange chromatography using Source Q resin (Buffer A: $50 \mathrm{mM}$ 1,3-bis 
(tris(hydroxymethyl)methylamino)propane (BTP, Sigma) with $10 \mu \mathrm{M}$ EDTA, pH 7.5; Buffer B: $50 \mathrm{mM}$ BTP, $10 \mu \mathrm{M}$ EDTA (Sigma) with $1 \mathrm{M} \mathrm{NaCl}, \mathrm{pH}$ 7.5). Fractions containing purified DHQase were pooled and concentrated.

2.5. Purification of PfuDHQS. In order to purify PfuDHQS efficiently, advantage was taken of the thermostability of $P f u$ DHQS to facilitate separation of the recombinant protein from E. coli host proteins [29]. E. coli Rosetta (DE3) cells containing the expression plasmid pT7-PfuDHQS were grown overnight at $37^{\circ} \mathrm{C}$ in LB medium supplemented with ampicillin $(100 \mu \mathrm{g} / \mathrm{mL})$ and chloramphenicol $(34 \mu \mathrm{g} / \mathrm{mL})$. This culture was used to inoculate $500 \mathrm{~mL}$ of fresh medium in a $1000 \mathrm{~mL}$ flask, and growth continued with shaking at $37^{\circ} \mathrm{C}$. Isopropyl- $\beta$-D-thiogalactopyranoside (IPTG) (Applichem) was added at $1 \mathrm{mM}$ to midlogarithmic phase cultures (OD600 0.6) to induce expression. Cells were harvested by centrifugation $\left(4^{\circ} \mathrm{C}, 4000 \mathrm{~g}, 20\right.$ minutes) 16 hours after induction. Cell pellets were frozen in liquid nitrogen and stored at $-80^{\circ} \mathrm{C}$ until required.

Cell pellets were thawed and resuspended in $50 \mathrm{mM}$ BTP buffer containing $2 \mathrm{mM}$ dithiothreitol (DTT) (BDH), $0.5 \mathrm{mM} \mathrm{NAD}^{+}$(Sigma), and $200 \mathrm{mM} \mathrm{KCl}$ (Ajax Chemicals), $\mathrm{pH} 6.8$ and lysed by sonication at $30^{\circ} \mathrm{C}$. The cell lysate was heat treated at $70^{\circ} \mathrm{C}$ for 20 minutes, cooled to $5^{\circ} \mathrm{C}$, and centrifuged $\left(4^{\circ} \mathrm{C}, 10000 \mathrm{~g}, 20\right.$ minutes).

$P f u$ DHQS was further purified by anion exchange chromatography using a Source Q 15 column (Amersham Biosciences). After filtering through a 0.45 -micron filter, the supernatant from the heat treatment step was diluted with buffer A (50 mM BTP with $10 \mu \mathrm{M}$ EDTA, pH 6.8) and loaded onto the anion exchange column. PfuDHQS was eluted at $90 \mathrm{mM} \mathrm{NaCl}$ by applying a linear gradient of $\mathrm{NaCl}$ at $2 \mathrm{~mL} / \mathrm{min}$ using buffer B ( $50 \mathrm{mM} \mathrm{BTP}, 10 \mu \mathrm{M}$ EDTA with $1 \mathrm{M} \mathrm{NaCl}, \mathrm{pH}$ 6.8). Fractions with DHQS activity were pooled and concentrated using a $10 \mathrm{kDa}$ MWCO (Vivascience). The concentrate was aliquoted $(50 \mu \mathrm{L})$, frozen in liquid nitrogen, and stored at $-80^{\circ} \mathrm{C}$.

2.6. Purification of PfuDHQase. E. coli Rosetta (DE3) cells, transformed with the expression plasmid pT7-PfuDHQase, were grown at $37^{\circ} \mathrm{C}$ in $\mathrm{LB}$ medium supplemented with ampicillin $(100 \mu \mathrm{g} / \mathrm{mL})$ and chloramphenicol $(34 \mu \mathrm{g} / \mathrm{mL})$. Expression of $P f u$ DHQase was induced with IPTG as described for PfuDHQS and purified based on the method of Schofield and coworkers [29]. Soluble protein from crude lysate was subjected to heat treatment at $70^{\circ} \mathrm{C}$ in lysis buffer (50 mM BTP, $2 \mathrm{mM} \mathrm{DTT,} 200 \mathrm{mM} \mathrm{KCl,} 1 \mathrm{mM}$ EDTA, $\mathrm{pH}$ 7.5). The resulting protein suspension was centrifuged to obtain supernatant which was then subjected to size exclusion chromatography on a Superdex S200 HR 10/300 column (Amersham Biosciences) and eluted under isocratic conditions at $0.4 \mathrm{~mL} / \mathrm{min}$ (Buffer: $10 \mathrm{mM}$ BTP, $10 \mu \mathrm{M}$ EDTA, $50 \mathrm{mM} \mathrm{KCl}, \mathrm{pH}$ 6.8). Fractions containing purified $P f u \mathrm{DHQ}$ ase were pooled and concentrated.

2.7. Synthesis and Quantification of DAH7P. DAH7P was prepared enzymatically from D-erythrose-4-phosphate (E4P,
Sigma) and phosphoenolpyruvate (PEP, Research Chemicals) using 3-deoxy-D-arabino-heptulosonate-7-phosphate synthase (DAH7PS, EC 2.5.1.54) as described by Hasan and Nester [7]. Additional aliquots of E. coli DAH7PS obtained from Dr. Fiona Cochrane (Massey University) were added until all PEP was consumed. The reaction was monitored by tracking the disappearance of PEP $\left(\varepsilon=2.8 \times 10^{3} \mathrm{M}^{-1} \mathrm{~cm}^{-1}\right.$ at $232 \mathrm{~nm}, \mathrm{pH} 6.8$ at $25^{\circ} \mathrm{C}$ ). The reaction mixture was filtered to remove the enzyme, the filtrate was loaded onto an anion exchange column, and the pooled fractions containing DAH7P were lyophilised. DAH7P concentrations were determined by the Lanzetta assay $[30,31]$. Standards (potassium dihydrogen phosphate) and samples were reacted with Lanzetta reagent, and the absorbance for each was read at $630 \mathrm{~nm}$.

2.8. DHQS Assays. To assess the activity of DHQS, in vitro experiments were performed spectrophotometrically using a coupled enzyme continuous assay [19]. This involved the DHQS-mediated conversion of DAH7P into DHQ followed by the 3-dehydroquinase-mediated conversion of DHQ to DHS $\left(\varepsilon=1.2 \times 10^{4} \mathrm{M}^{-1} \mathrm{~cm}^{-1}\right.$ at $\left.234 \mathrm{~nm}\right)$. When $3-$ dehydroquinase is present in excess (at least 10 times the concentration of DHQS), this assay provides a quantitative measure of DHQS activity. An extinction coefficient of 1.2 $\times 10^{4} \mathrm{M}^{-1} \mathrm{~cm}^{-1}$ was used in all calculations of activities at $25^{\circ} \mathrm{C}$ for $E c o$ DHQS and $60^{\circ} \mathrm{C}$ for $P f u$ DHQS.

To determine the kinetics of PfuDHQS for DAH7P, a reaction mixture was prepared containing DAH7P (1 to $70 \mu \mathrm{M}), \mathrm{ZnCl}_{2}(100 \mu \mathrm{M})(\mathrm{BDH})$, and $\mathrm{NAD}^{+}(29 \mu \mathrm{M})$ in $50 \mathrm{mM}$ BTP buffer with $10 \mu \mathrm{M}$ EDTA, pH 6.8 at $60^{\circ} \mathrm{C}$. The mixture was preincubated at $60^{\circ} \mathrm{C}$ for 1 minute followed by addition of $P f u D H Q$ ase $(826 \mathrm{nM})$. The reaction was initiated by the addition of $P f u$ DHQS $(56 \mathrm{nM})$. The final volume was $1000 \mu \mathrm{L} . K_{M}$ and $k_{\text {cat }}$ values were determined by fitting the data to the Michaelis-Menten equation using GraFit 5 (Erithacus Software Limited, 2006). Enzyme concentrations are stated as monomer concentrations.

The extinction coefficient of DHS at various temperatures was determined by measuring the total conversion of DAH7P to DHS. The reaction mixture was prepared as above except that the concentration of DAH7P used was $117 \mu \mathrm{M}$ and the $\mathrm{pH}$ at each of the required temperatures was adjusted to 6.8. The reaction was initiated by the addition of PfuDHQS (5.6 nM). A correction for the change in absorbance due to the addition of enzyme was determined using reaction mixtures without DAH7P.

2.9. Stability of DAH7P. The stability of DAH7P was determined by incubating several $5 \mu \mathrm{L}$ aliquots of DAH7P at $60^{\circ} \mathrm{C}$. At appropriate time intervals, a $5 \mu \mathrm{L}$ aliquot of DAH7P was added to a cuvette containing EcoDHQase $(1.46 \mu \mathrm{M}), \mathrm{ZnCl}_{2}$ $(100 \mu \mathrm{M})$, and $\mathrm{NAD}^{+}(29 \mu \mathrm{M})$ in $50 \mathrm{mM}$ BTP buffer with $10 \mu \mathrm{M}$ EDTA at $\mathrm{pH} 6.8$ and allowed to incubate at $25^{\circ} \mathrm{C}$. The amount of DAH7P was determined by measuring the total conversion of DAH7P to DHS $\left(\varepsilon=1.2 \times 10^{4} \mathrm{M}^{-1} \mathrm{~cm}^{-1}\right.$ at $234 \mathrm{~nm}, \mathrm{pH} 6.8$ at $25^{\circ} \mathrm{C}$ ) by the addition of EcoDHQS $(7 \mathrm{nM})$ to the reaction mixture. 


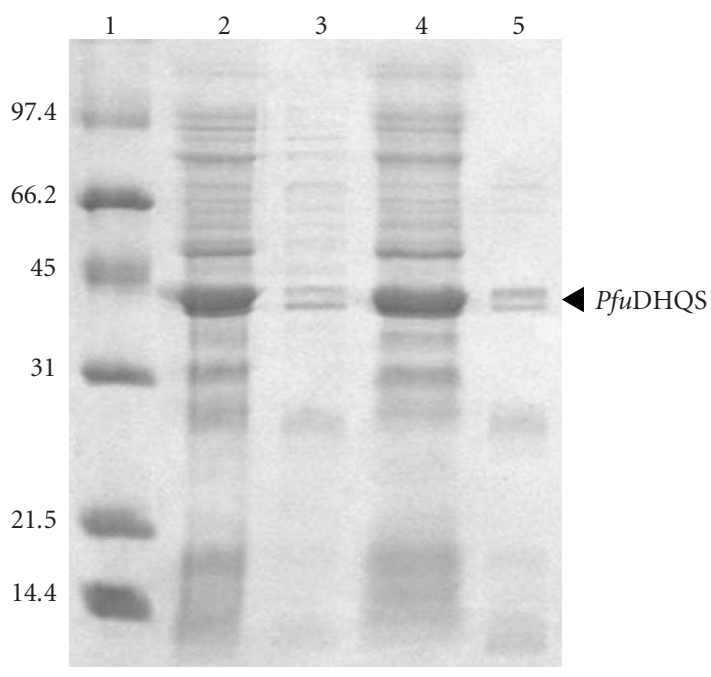

(a)

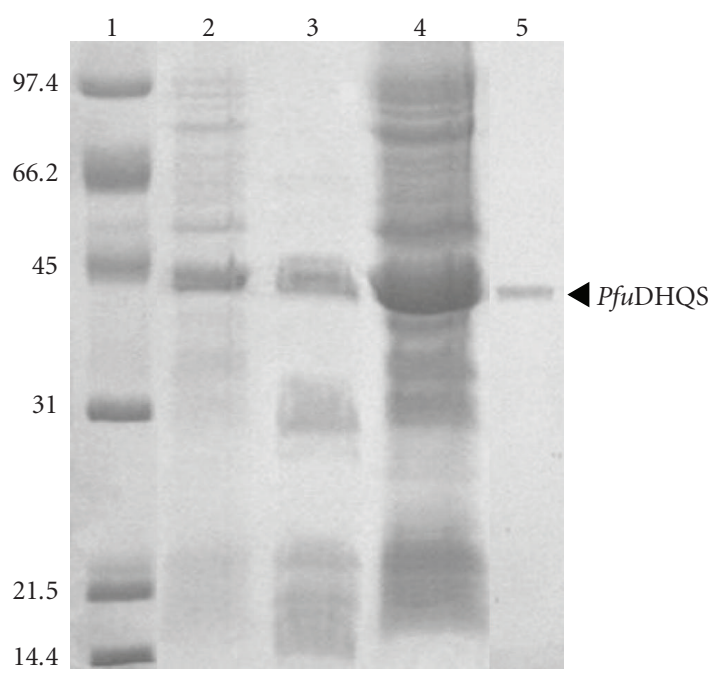

(b)

FIgure 1: SDS-PAGE analysis of PfuDHQS. (a) Protein obtained from cell lysis under low-salt conditions. (1) Marker; (2) total crude; (3) soluble crude (supernatant obtained from centrifugation of the total crude); (4) insoluble crude (resuspended pellet, in $6 \mathrm{M}$ urea, obtained from centrifugation of the total crude); (5) soluble heat treated (supernatant obtained from heat-treated soluble crude). (b) Protein obtained from cell lysis under high-salt conditions. (1) Marker; (2) total crude; (3) soluble heat treated; (4) insoluble heat treated; (5) anion exchange.

TABle 1: Purification of recombinant PfuDHQS from E. coli.

\begin{tabular}{lccccc}
\hline Step & Total protein $(\mathrm{mg})$ & $\begin{array}{c}\text { Total enzyme } \\
\text { activity }(\mathrm{U})\end{array}$ & $\begin{array}{c}\text { Calculated specific } \\
\text { activity }\left(\mathrm{U} \mathrm{mg}^{-1}\right)\end{array}$ & Yield (\%) & Approximate purity \\
\hline Total crude & 46 & 18 & 0.17 & 100 & 1 \\
Heat treated & 6.7 & 13 & 1.9 & 72 & 11 \\
Anion exchange & 3.2 & 11 & 3.2 & 59 & 19 \\
\hline
\end{tabular}

2.10. Effect of Temperature on PfuDHQS Activity. Assays to determine the effect of temperature on enzymatic activity contained $50 \mathrm{mM}$ BTP buffer with $10 \mu \mathrm{M}$ EDTA adjusted to $\mathrm{pH} 6.8$ at the temperature of use. The reaction mixture was prepared as for the DHQS kinetics assay except that the concentration of DAH7P used was $21 \mu \mathrm{M}$. Specific activities at 40,60 , and $80^{\circ} \mathrm{C}$ were inferred using the extinction coefficients for DHS determined at each temperature. Specific activities at $25,30,50$, and $70^{\circ} \mathrm{C}$ were determined using calculated extinction coefficients.

2.11. Effect of $p H$ on PfuDHQS Activity. Assays to determine the effect of $\mathrm{pH}$ on enzymatic activity contained $50 \mathrm{mM}$ BTP buffer with $10 \mu \mathrm{M}$ EDTA adjusted to the required $\mathrm{pH}$ at $60^{\circ} \mathrm{C}$. The reaction mixture was prepared as above. Specific activities at $\mathrm{pH} 5.9,6.4,6.7,6.9,7.4,7.7,7.9,8.4$, and 9.4 were calculated using an extinction coefficient of $1.2 \times$ $10^{4} \mathrm{M}^{-1} \mathrm{~cm}^{-1}$.

2.12. Metal Dependency. Reaction mixtures to determine the activity of $P f u D H Q S$ in the absence of divalent metal ions contained DAH7P $(46 \mu \mathrm{M})$ and $\mathrm{NAD}^{+}(29 \mu \mathrm{M})$ in $50 \mathrm{mM}$ BTP buffer with $10 \mu \mathrm{M}$ EDTA, $\mathrm{pH} 6.8_{60}^{\circ} \mathrm{C}$ pretreated with Chelex 100 resin (Bio-Rad). Reaction mixtures and $P f u D H Q S$ samples were pretreated for 10 minutes at $21^{\circ} \mathrm{C}$ with EDTA ( $100 \mu \mathrm{M}$ and $1 \mathrm{mM}$, resp.) with the exception of one PfuDHQS sample that was not treated with EDTA. All the reaction mixtures were preincubated at $60^{\circ} \mathrm{C}$ for 5 minutes followed by addition of PfuDHQase $(330 \mathrm{nM})$. The reactions were initiated by the addition of EDTAtreated $P f u$ DHQS $(11 \mathrm{nM})$ with the exception of one reaction mixture which was initiated by the addition of PfuDHQS $(11 \mathrm{nM})$ that was not treated with EDTA. Divalent metal ion salts used in assays to restore activity to the EDTAtreated PfuDHQS were dissolved in $50 \mathrm{mM}$ BTP buffer, $\mathrm{pH}$ $6.8_{60}{ }^{\circ} \mathrm{C}$ pretreated with Chelex to give a final concentration of $0.1 \mathrm{mM}$ in the reaction mixture. The metal salts used were $\mathrm{CoCl}_{2} \cdot 6 \mathrm{H}_{2} \mathrm{O}$ (Sigma), $\mathrm{BaCl}_{2} \cdot 2 \mathrm{H}_{2} \mathrm{O}(\mathrm{BDH}), \mathrm{FeSO}_{4} \cdot 7 \mathrm{H}_{2} \mathrm{O}$ (Sigma), $\mathrm{MgSO}_{4} \cdot \mathrm{H}_{2} \mathrm{O}$ (May and Baker), $\mathrm{CaCl}_{2}$ (Prolabo), $\mathrm{MnSO}_{4} \cdot \mathrm{H}_{2} \mathrm{O}$ (Sigma), $\mathrm{CrCl}_{2}$ (Aldrich), $\mathrm{HgCl}_{2}$ (Aldrich), $\mathrm{CdCl}_{2}$ (May and Baker), $\mathrm{NiCl}_{2} \cdot 6 \mathrm{H}_{2} \mathrm{O}$ (May and Baker), $\mathrm{CuSO}_{4} \cdot \mathrm{H}_{2} \mathrm{O}$ (May and Baker), and $\mathrm{ZnCl}_{2}$.

2.13. Molecular Weight Determination. The molecular weight of $P f u D H Q S$ was determined by electrospray ionisation mass spectrometry (ESI-MS) on a Micromass LCT TOF instrument, equipped with an ESI probe. Protein samples $(10 \mu \mathrm{g} / \mathrm{mL})$ were prepared in $50 \%$ acetonitrile and water and directly injected at $20 \mu \mathrm{L} / \mathrm{mL}$. Samples were analysed with a cone voltage of $25 \mathrm{~V}$ and a probe voltage of 


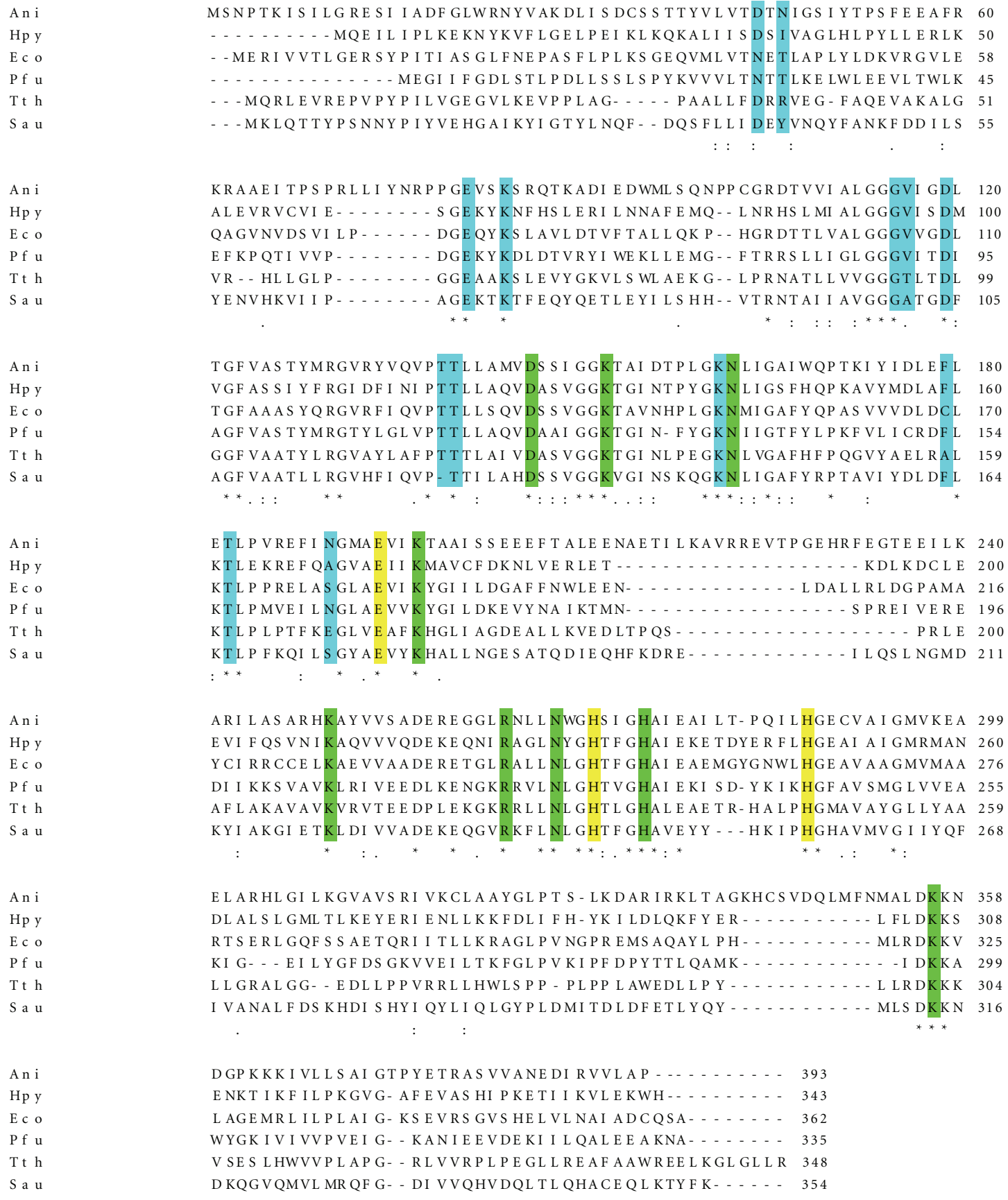

FIgURe 2: Sequence alignment for PfuDHQS and EcoDHQS with characterised DHQSs (Ani: A. nidulans DHQS, Hpy: H. pylori DHQS, Eco: E. coli DHQS, Pfu: P. furiosus DHQS, Tth: T. thermophilus DHQS, Sau: S. aureus DHQS). Residues highlighted in yellow are metal binding ligands. Residues associated with substrate binding are highlighted in green, and cofactor $\mathrm{NAD}^{+}$binding residues are highlighted in blue.

3,200 V. This system was controlled by MassLynx (version 4.0) software.

The native molecular weight was determined by size exclusion chromatography. Filtered samples of partially purified protein at concentrations of $\leq 10 \mathrm{mg} / \mathrm{mL}$ were applied to a Superdex S200 HR 10/300 column (Amersham Biosciences) in $10 \mathrm{mM}$ BTP buffer containing $10 \mu \mathrm{M}$ EDTA, $50 \mathrm{mM} \mathrm{KCl}$ at $\mathrm{pH}$ 6.8. A standard curve was generated using cytochrome C (12.4 kDa, Sigma), carbonic anhydrase
TAble 2: Kinetic constants of PfuDHQS and EcoDHQS with DAH7P.

\begin{tabular}{lccc}
\hline Enzyme & $K_{M}(\mu \mathrm{M})$ & $k_{\text {cat }}\left(\mathrm{s}^{-1}\right)$ & $k_{\text {cat }} / K_{M}\left(\mu \mathrm{M}^{-1} \mathrm{~s}^{-1}\right)$ \\
\hline PfuDHQS & $3.7 \pm 0.2$ & $3.0 \pm 0.1$ & 0.8 \\
EcoDHQS & $6.3 \pm 0.2$ & $16.0 \pm 0.2$ & 2.5 \\
\hline
\end{tabular}

(29kDa, Sigma), bovine serum albumin (66 kDa, Sigma), alcohol dehydrogenase $(150 \mathrm{kDa}$, Sigma $)$, and $\beta$-amylase 


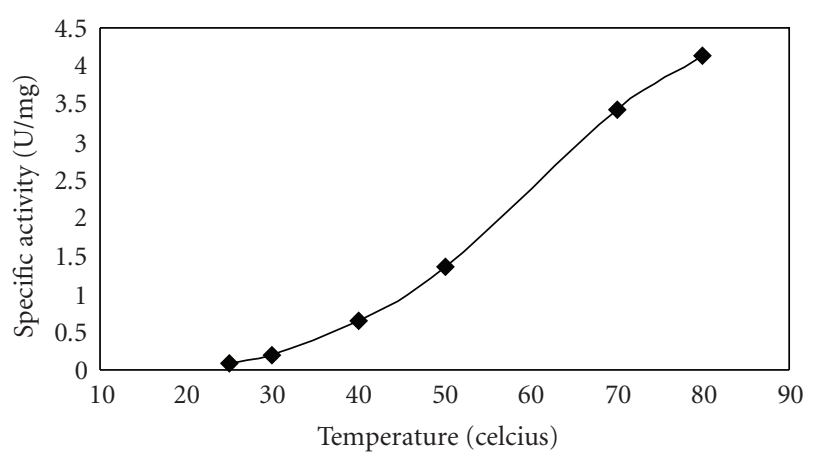

FIGURE 3: Effects of temperature on specific activity of purified $P f u$ DHQS.

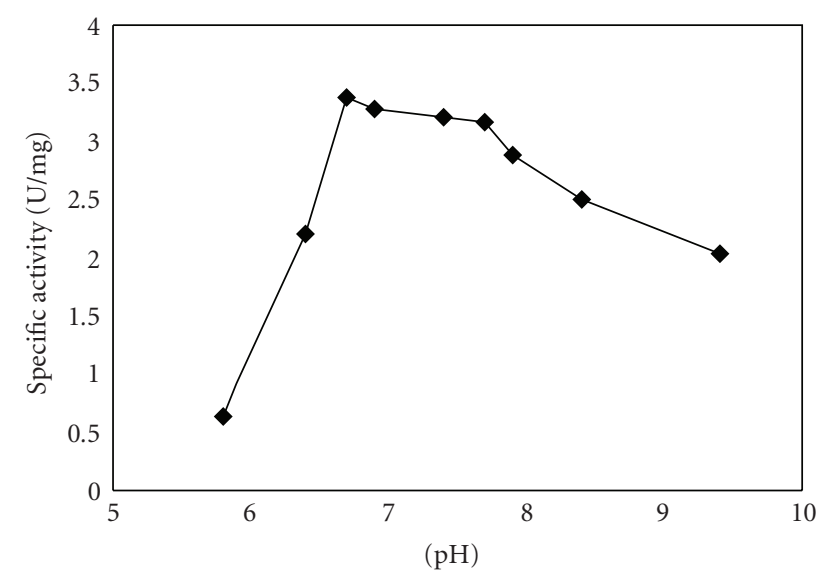

FIgURE 4: Effects of $\mathrm{pH}$ on the specific activity of purified $P f u$ DHQS.

(200 kDa, Sigma). The molecular weight was estimated from a curve prepared by plotting the log of the molecular weight of the standards versus the elution time.

2.14. Thermal Stability. Circular dichroism (CD) spectroscopic data were generated using a Jasco J-815 CD spectrophotometer. Spectra were collected at a concentration of $0.01 \mathrm{mg} / \mathrm{mL}$ of enzyme in water. Wavelength scans were collected at $20^{\circ} \mathrm{C}$ using a $10 \mathrm{mM}$ path-length cuvette, $1.0 \mathrm{~nm}$ bandwidth, $0.5 \mathrm{~nm}$ step size, and a 1 -second averaging time. Temperature scans were monitored at $220 \mathrm{~nm}$, and data were collected at $0.5^{\circ} \mathrm{C}$ intervals between 20 to $90^{\circ} \mathrm{C}$ with a 1-second averaging time. Cuvettes were stoppered during temperature scans to prevent evaporation.

Fluorescence-based protein thermal stability assays were carried out as described previously [32]. A $25 \mu \mathrm{L}$ aliquot of solution containing $0.5 \mathrm{mg} / \mathrm{mL}$ of protein, $50 \mathrm{mM}$ sodium phosphate buffer at $\mathrm{pH} 8.0$, and $2.5 \mu \mathrm{L}$ of 10XSypro Orange dye (Invitrogen) was added to the wells of a 96-well thinwall PCR plate (Bio-Rad). The plates were sealed and heated in an iCycleriQ Real-Time PCR Detection System (BioRad) from 20 to $100^{\circ} \mathrm{C}$ in increments of $0.5^{\circ} \mathrm{C}$, with 30 second dwell time. Fluorescence changes in the wells of the plate were monitored simultaneously with a charge-coupled
TABle 3: Activation of EDTA-treated DHQS by various divalent metal ions. The activity of EDTA-treated PfuDHQS in the presence of a range of other divalent metal ions is given as a percentage of the activity seen for the $\mathrm{Cd}^{2+}$-activated enzyme.

\begin{tabular}{lc}
\hline Divalent metal ion & $P f u$ DHQS activity $(\%)$ \\
\hline $\mathrm{Cd}$ & 100 \\
$\mathrm{Co}$ & 82 \\
$\mathrm{Zn}$ & 71 \\
$\mathrm{Mn}$ & 41 \\
$\mathrm{Ni}$ & 3 \\
$\mathrm{Fe}$ & 2 \\
$\mathrm{Cu}$ & 2 \\
$\mathrm{Ca}$ & 2 \\
$\mathrm{Hg}$ & 2 \\
$\mathrm{Mg}$ & 1 \\
$\mathrm{Ba}$ & 0 \\
$\mathrm{Cr}$ & 0 \\
No metal & 1 \\
No metal/EDTA treated & 0.1 \\
\hline
\end{tabular}

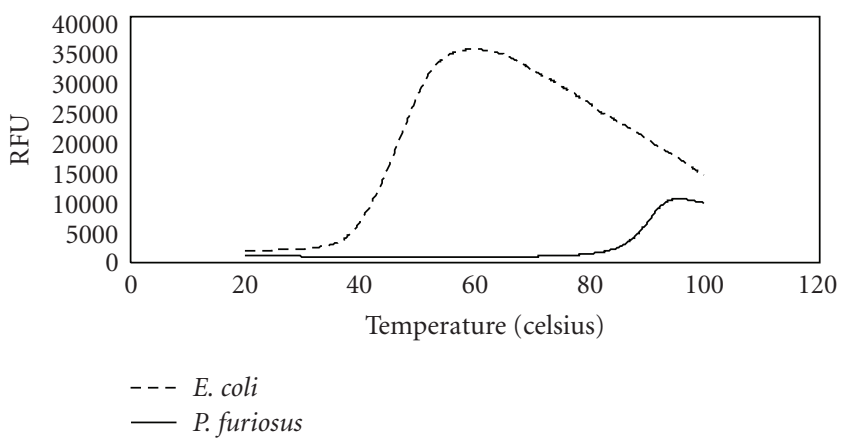

FIGURE 5: Fluorescence-based thermal stability assay of PfuDHQS and EcoDHQS.

device camera. The wavelengths for excitation and emission were 490 and $575 \mathrm{~nm}$, respectively. Experiments were carried out in triplicate.

2.15. Miscellaneous Methods. Polyacrylamide gel electrophoresis (PAGE) in the presence of sodium dodecyl sulfate (SDS) was performed by the method of Laemmli (1970) with a $4 \%$ $(\mathrm{w} / \mathrm{v})$ stacking gel and a $12 \%(\mathrm{w} / \mathrm{v})$ resolving gel, using a Mini-Protean III cell (Bio-Rad). Samples were prepared in a loading buffer containing SDS, boiled for 2 minutes, and loaded within 10 minutes. Low-range SDS-PAGE molecular weight standards (Bio-Rad) were used. After electrophoresis, gels were stained for protein using Coomassie Brilliant Blue R 250 (Park Scientific).

Protein concentrations were determined by the method of Bradford, using bovine serum albumin as a standard [33].

\section{Results and Discussion}

3.1. Protein Expression and Purification. The gene encoding $P f u$ DHQS was amplified from $P$. furiosus genomic DNA. The 


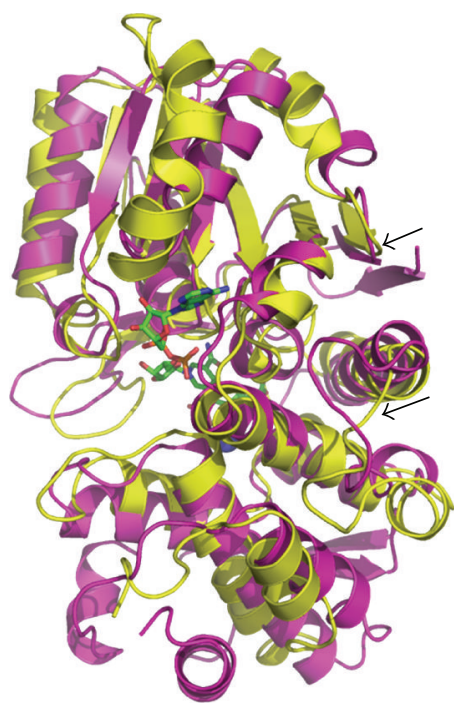

(a)

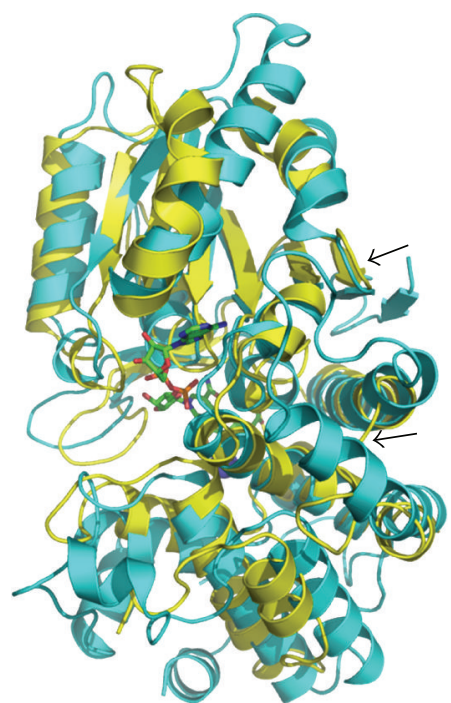

(b)

FIGUre 6: Overlay of modelled PfuDHQS with the structures of A. nidulans DHQS and T. thermophilus DHQS. PfuDHQS was modelled using PRIME 1.5 based on the structure of S. aureus DHQS (1XAI). (a) Overlay of modelled PfuDHQS (yellow) with A. nidulans (1SG6, magenta). (b) Overlay of modelled PfuDHQS (yellow) with T. thermophilus DHQS (1UJN, cyan). Structures of the ligands, NAD ${ }^{+}$and the carbaphosphonate analogue of DAH7P, are shown by green sticks (from 1SG6). The arrows indicate the position of the N-terminus (top) and the loop around Glu194, where loops are predicted to be considerably shorter in PfuDHQS.

PCR product was purified by agarose gel electrophoresis, digested with NdeI and BamHI, and ligated to similarly digested pT7-7. The resulting pT7-PfuDHQS construct was sequenced to confirm the integrity of the PfuDHQS gene and transformed into E. coli Rosetta (DE3) cells. After induction with IPTG, cell lysis, and centrifugation, SDS-PAGE analysis indicated that the protein was largely insoluble (Figure 1(a)). However, adjusting the salt concentration in the lysis buffer to $200 \mathrm{mM} \mathrm{KCl}$ substantially increased the solubility of the enzyme (Figure 1(b)).

Kosmotropes such as $\mathrm{KCl}$ have been shown to influence protein aggregation and solubility [34].

A three-step purification protocol was devised to yield homogeneous DHQS. Following cell lysis at $30^{\circ} \mathrm{C}$ and heat treatment to remove nonthermostable contaminants, DHQS was subjected to anion exchange chromatography (Figure 1(b)). Although there was a substantial loss of protein during this step, the overall purity of PfuDHQS compared to that in the crude lysate increased by 19fold (Table 1). A $500 \mathrm{~mL}$ culture yielded $3.2 \mathrm{mg}$ of purified recombinant $P f u$ DHQS.

3.2. Characterisation of PfuDHQS. The relative molecular mass of the purified recombinant PfuDHQS was 37,397 $\pm 5 \mathrm{Da}$ for the monomer as determined by ESI-MS. This value is in close agreement with the value calculated from the sequence $(37,394 \mathrm{Da})$. A single peak was observed by size exclusion chromatography corresponding to a mass of $72 \mathrm{kDa}$. This result is consistent with recombinant $P f u \mathrm{DHQS}$ existing as a homodimer in solution. A. nidulans and T. thermophilus DHQS enzymes are also reported to be homodimeric in their crystalline form $[10,12]$. A multiple sequence alignment (Figure 2) including $P f u D H Q S$ and other characterised enzymes indicates that of these proteins $P f u$ DHQS shares the greatest sequence identity with the DHQS from E. coli (37\%). Slightly lower identity is observed between PfuDHQS and the structurally characterised DHQS from the thermophilic bacterium T. thermophilus (32\%). T. thermophilus has an optimal growth temperature of $65^{\circ} \mathrm{C}$.

The spectrophotometric coupled enzyme assay used to assess the activity of $P f u D H Q S$ was optimised to function at $60^{\circ} \mathrm{C}$. At temperatures above $60^{\circ} \mathrm{C}$, gas bubbles developed in the cuvette interfering with the assay. Furthermore, handling of cuvettes became difficult above $60^{\circ} \mathrm{C}$. All cuvettes contained DAH7P, a divalent metal, and $\mathrm{NAD}^{+}$in buffer at $\mathrm{pH} 6.8_{60^{\circ} \mathrm{C}}$ and were preheated at $60^{\circ} \mathrm{C}$. After 5 minute of preincubation, $P f u$ DHQase was added to the cuvette and the reaction mixture allowed to heat a further minute at $60^{\circ} \mathrm{C}$. The reaction was initiated by the addition of $P f u D H Q S$, and the rate of DHS production was monitored at $234 \mathrm{~nm}$. It is important to note that the stability of DAH7P at $60^{\circ} \mathrm{C}$ was examined, and results showed that DAH7P was stable for at least 30 minutes at $60^{\circ} \mathrm{C}$. The extinction coefficient of DHS was found to decrease slightly above $60^{\circ} \mathrm{C}$. An extinction coefficient of $1.2 \times 10^{4} \mathrm{M}^{-1} \mathrm{~cm}^{-1}$ was used in all calculations of activities at $60^{\circ} \mathrm{C}$.

PfuDHQS exhibits standard Michaelis-Menten kinetics. The kinetic constants of PfuDHQS were $K_{M} 3.7 \pm 0.2 \mu \mathrm{M}$ and $k_{\text {cat }} 3.0 \pm 0.1 \mathrm{~s}^{-1}$, at $60^{\circ} \mathrm{C}$ and $\mathrm{pH}$ 6.8. A comparison of the kinetic constants of PfuDHQS with those of EcoDHQS (at $25^{\circ} \mathrm{C}$ and $\mathrm{pH}$ 6.8) shows a higher $k_{\text {cat }}$ for EcoDHQS than PfuDHQS (Table 2). Some of the difference in $k_{\text {cat }}$ between EcoDHQS and PfuDHQS could be due to the assay 
for $P f u$ DHQS having been carried out at a suboptimal temperature for this enzyme.

Although the structure of DHQS from the moderate thermophile $T$. thermophilus has been determined, this is the first report of the biochemical characterisation of DHQS from any thermophile or hyperthermophile.

The effect of temperature on $P f u D H Q S$ activity showed an initial rise in activity proportional to the rise in temperature. However, the activity begins to taper off above $75^{\circ} \mathrm{C}$ (Figure 3). At $60^{\circ} \mathrm{C}$, the activity of $P f u D H Q S$ is highest at $\mathrm{pH} 6.8$, but the range for optimum activity is broader at approximately 6.7 to 7.8 (Figure 4 ).

3.3. Metal Dependency of Enzyme Activity. It has been shown for DHQS enzymes from E. coli, B. subtilis, A. nidulans, $N$. crassa, P. sativum and Sorghum sp. that a divalent metal ion is required for enzymatic activity $[7,14,16,19,35,36]$. Treatment of these enzymes with EDTA resulted in the rapid formation of inactive apoenzyme that could be reactivated by the addition of various divalent metal ions. Zinc, found in the active site of DHQS, has been suggested to be the naturally occurring metal ion for E. coli, A. nidulans, and N. crassa enzymes $[14,19,35]$.

The residual activity of $P f u D H Q S$ in the absence of added metal (no metal, Table 3 ) decreased 10 -fold when this sample was treated with $1 \mathrm{mM}$ EDTA. A range of divalent metal ions were tested for their ability to restore activity to EDTAtreated $P f u$ DHQS (Table 3). The EDTA-treated PfuDHQS was activated 1000 -fold by cadmium, and to a lesser extent by other metal ions. The cadmium and cobalt forms of $P f u$ DHQS were both significantly more active than the zincactivated enzyme.

A survey of the metal dependency of other DHQSs reported in the literature showed that cobalt was the predominant activating metal in all screens $[6,7,14,16,19]$. For example, cobalt restored the activity of $A$. nidulans DHQS to $125 \%$ of the level observed with zinc. In addition, cobalt activated DHQS from Phaseolus mungo and Sorghum bicolour [16]. Furthermore, manganese and cobalt were the only divalent metals that activated DHQS from Bacillus subtilis [7]. In contrast to A. nidulans DHQS, results for PfuDHQS showed that cadmium was able to activate the enzyme to a greater extent than zinc. Cobalt only restored the activity of $P f u D H Q S$ to $82 \%$ of that seen with cadmium. Similar to the observations made for A. nidulans DHQS, iron and nickel were poor activators of $P f u$ DHQS ( $2 \%$ and $3 \%$, resp.) although the activity seen with $A$. nidulans DHQS [6] was greater (18\% with iron, and $16 \%$ with nickel). Of the DHQSs that have been characterised, cadmium has not been shown to activate other DHQS enzymes to the level seen with $P f u D H Q S$. However, when comparing PfuDHQS with $P$. furiosus DAH7PS, a preference for $\mathrm{Cd}^{2+}$ can be seen. Schofield and coworkers showed that $\mathrm{Cd}^{2+}$ significantly activated P. furiosus DAH7PS over $\mathrm{Mn}^{2+}$ and $\mathrm{Co}^{2+}(162 \%$, $100 \%$, and $68 \%$, resp.) [29]. These enzymes appear to be relatively tolerant to a range of divalent metal ions for the support of catalytic activity. The preference for cadmium may be indicative of the increased bioavailability of this metal and the tolerance of organisms such as $P$. furiosus to cadmium $[37,38]$.

3.4. Thermal Stability of PfuDHQS. The thermal stability of $P f u$ DHQS and EcoDHQS was examined using CD spectroscopy by monitoring the changes in the secondary structure at wavelengths in the far UV. As expected, PfuDHQS was significantly more thermostable than EcoDHQS. Loss of secondary structure was observed at 90 and $30^{\circ} \mathrm{C}$ for $P f u D H Q S$ and EcoDHQS, respectively, (data not shown).

Differential scanning fluorimetry [32] was used to determine the thermal stability of DHQS and to confirm the results seen with $\mathrm{CD}$ spectroscopy. Using this technique, the $T_{m}$ for $P f u$ DHQS was found to be $90^{\circ} \mathrm{C}$, whereas the $T_{m}$ for EcoDHQS was $45^{\circ} \mathrm{C}$ (Figure 5). Sequence comparison indicates that PfuDHQS is the shortest of the DHQS enzymes. Homology modelling of the enzyme indicates that the PfuDHQS monomer has a truncated N-terminus and is likely to include shorter loops between secondary structure elements, most notably in the region around Glu194 (Figure 6). These predicted structural changes may explain the relative thermostability of this protein.

\section{Conclusions}

Recombinant $P f u D H Q S$ overexpressed in E. coli Rosetta (DE3) cells was purified in a soluble active form. This success was largely due to the high-salt content in the lysis buffer that contributed to a higher yield of soluble protein. Characterisation of the enzyme revealed that recombinant $P f u D H Q S$ assembles as a homodimer with a monomeric molecular weight of $37.4 \mathrm{kDa}$. The enzyme is structurally stable and active up to $90^{\circ} \mathrm{C}$ and is activated by $\mathrm{Cd}^{2+}, \mathrm{Co}^{2+}$, $\mathrm{Zn}^{2+}$, and $\mathrm{Mn}^{2+}$. High enzymatic activities in the presence of $\mathrm{Cd}^{2+}$ have not previously been observed for this enzyme from other sources.

\section{Abbreviations}

$\begin{array}{ll}\text { Pfu: } & \text { Pyrococcus furiosus } \\ \text { DHQ: } & \text { Dehydroquinate } \\ \text { DHS: } & \text { Dehydroshikimate } \\ \text { DHQS: } & \text { Dehydroquinate synthase } \\ \text { DHQase: } & \text { 3-Dehydroquinase } \\ \text { DAH7P: } & \text { 3-deoxy-D-arabino-heptulosonate } \\ & \text { 7-phosphate } \\ \text { BTP: } & \text { 1,3-bis(tris(hydroxymethyl) } \\ & \text { methylamino)propane } \\ \text { NADH: } & \beta \text {-nicotinamide adeninedinucleotide } \\ \text { EDTA: } & \text { Ethylenediaminetetraacetic acid } \\ \text { IPTG: } & \text { Isopropyl- } \beta \text {-D-thiogalactopyranoside } \\ \text { DTT: } & \text { Dithiothreitol } \\ \text { MWCO: } & \text { Molecular weight cutoff } \\ \text { SDS-PAGE: } & \text { Sodium dodecyl sulfate-polyacrylamide } \\ & \text { gel electrophoresis } \\ \text { MW: } & \text { Molecular weight } \\ \text { PEP: } & \text { Phosphoenolpyruvate } \\ \text { E4P: } & \text { Erythrose 4-phosphate }\end{array}$


ESI-MS: Electrospray ionisation mass spectrometry

Mr: $\quad$ Relative molecular weight

PCR: Polymerase chain reaction

RCSB: Research Collaboratory for Structural Bioinformatics.

\section{Acknowledgments}

The authors thank Dr. Linley Schofield for technical assistance and Professor Geoffrey Jameson for useful suggestions in the course of this study.

\section{References}

[1] B. Ganem, "From glucose to aromatics: recent developments in natural products of the shikimic acid pathway," Tetrahedron, vol. 34, no. 22, pp. 3353-3383, 1978.

[2] S. M. Kapnick and Y. Zhang, "New tuberculosis drug development: targeting the shikimate pathway," Expert Opinion on Drug Discovery, vol. 3, no. 5, pp. 565-577, 2008.

[3] J. R. Coggins, C. Abell, L. B. Evans et al., "Experiences with the shikimate-pathway enzymes as targets for rational drug design," Biochemical Society Transactions, vol. 31, no. 3, pp. 548-552, 2003.

[4] R. Bentley, "The shikimate pathway-a metabolic tree with many branches," Critical Reviews in Biochemistry and Molecular Biology, vol. 25, no. 5, pp. 307-384, 1990.

[5] A. R. Hawkins, J. D. Moore, and A. M. Adeokun, "Characterization of the 3-dehydroquinase domain of the pentafunctional AROM protein, and the quinate dehydrogenase from Aspergillus nidulans, and the overproduction of the type II 3dehydroquinase from Neurospora crassa," Biochemical Journal, vol. 296, no. 2, pp. 451-457, 1993.

[6] J. D. Moore, J. R. Coggins, R. Virden, and A. R. Hawkins, "Efficient independent activity of a monomeric, monofunctional dehydroquinate synthase derived from the N-terminus of the pentafunctional AROM protein of Aspergillus nidulans," Biochemical Journal, vol. 301, no. 1, pp. 297-304, 1994.

[7] N. Hasan and E. W. Nester, "Dehydroquinate synthase in Bacillus subtilis. An enzyme associated with chorismate synthase and flavin reductase," Journal of Biological Chemistry, vol. 253, no. 14, pp. 4999-5004, 1978.

[8] J. W. Frost, J. L. Bender, J. T. Kadonaga, and J. R. Knowles, "Dehydroquinate synthase from Escherichia coli: purification, cloning, and construction of overproducers of the enzyme," Biochemistry, vol. 23, no. 19, pp. 4470-4475, 1984.

[9] P. R. Srinivasan, J. Rothschild, and D. B. Sprinson, "The enzymic conversion of 3-deoxy-D-arabino-heptulosonic acid 7-phosphate to 5-dehydroquinate," The Journal of Biological Chemistry, vol. 238, pp. 3176-3182, 1963.

[10] E. P. Carpenter, A. R. Hawkins, J. W. Frost, and K. A. Brown, "Structure of dehydroquinate synthase reveals an active site capable of multistep catalysis," Nature, vol. 394, no. 6690, pp. 299-302, 1998.

[11] A. Günel-Özcan, K. A. Brown, A. G. Allen, and D. J. Maskell, "Salmonella typhimurium aroB mutants are attentuated in BALB/c mice," Microbial Pathogenesis, vol. 23, no. 5, pp. 311316, 1997.

[12] M. Sugahara, Y. Nodake, M. Sugahara, and N. Kunishima, "Crystal structure of dehydroquinate synthase from Thermus thermophilus HB8 showing functional importance of the dimeric state," Proteins, vol. 58, no. 1, pp. 249-252, 2005.

[13] J. S. Liu, W. C. Cheng, H. J. Wang, Y. C. Chen, and W. C. Wang, "Structure-based inhibitor discovery of Helicobacter pylori dehydroquinate synthase," Biochemical and Biophysical Research Communications, vol. 373, no. 1, pp. 1-7, 2008.

[14] J. M. Lambert, M. R. Boocock, and J. R. Coggins, "The 3dehydroquinate synthase activity of the pentafunctional arom enzyme complex of Neurospora crassa is $\mathrm{Zn}^{2+}$ dependent," Biochemical Journal, vol. 226, no. 3, pp. 817-829, 1985.

[15] E. Yamamoto, "Purification and metal requirements of 3dehydroquinate synthase from Phaseolus mungo seedlings," Phytochemistry, vol. 19, no. 5, pp. 779-781, 1980.

[16] R. Saijo and T. Kosuge, "The conversion of 3-deoxy-arabinoheptulosonate 7-phosphate to 3-dehydroquinate by sorghum seedling preparations," Phytochemistry, vol. 17, no. 2, pp. 223225, 1978.

[17] C. E. Nichols, J. Ren, K. Leslie et al., "Comparison of ligandinduced conformational changes and domain closure mechanisms, between prokaryotic and eukaryotic dehydroquinate synthases," Journal of Molecular Biology, vol. 343, no. 3, pp. 533-546, 2004.

[18] P. T. H. Ngo, S. Natarajan, H. Kim et al., "Cloning, expression, crystallization and preliminary X-ray crystallographic analysis of 3-dehydroquinate synthase, Xoo1243, from Xanthomonas oryzae pv. oryzae," Acta Crystallographica Section F, vol. 64, no. 12, pp. 1128-1131, 2008.

[19] S. L. Bender, S. Mehdi, and J. R. Knowles, "Dehydroquinate synthase: the role of divalent metal cations and of nicotinamide adenine dinucleotide in catalysis," Biochemistry, vol. 28, no. 19, pp. 7555-7560, 1989.

[20] S. L. Rotenberg and D. B. Sprinson, "Mechanism and stereochemistry of 5-dehydroquinate synthetase," Proceedings of the National Academy of Sciences of the United States of America, vol. 67, no. 4, pp. 1669-1672, 1970.

[21] S. L. Rotenberg and D. B. Sprinson, "Isotope effects in 3dehydroquinate synthase and dehydratase. Mechanistic implications," Journal of Biological Chemistry, vol. 253, no. 7, pp. 2210-2215, 1978.

[22] M. J. Turner, B. W. Smith, and E. Haslam, "The shikimate pathway. Part IV. The stereochemistry of the 3-dehydroquinate dehydratase reaction and observations on 3-dehydroquinate synthetase," Journal of the Chemical Society, Perkin Transactions 1, no. 1, pp. 52-55, 1975.

[23] B. N. Ames, "Assay of inorganic phosphate, total phosphate and phosphatases," in Methods Enzymol, E. Neufeld and V. Ginsburg, Eds., pp. 115-118, Academic Press, New York, NY, USA, 1966.

[24] U. S. Maitra and D. B. Sprinson, "5-Dehydro-3-deoxy-Darabino-heptulosonic acid 7-phosphate. An intermediate in the 3-dehydroquinate synthase reaction," Journal of Biological Chemistry, vol. 253, no. 15, pp. 5426-5430, 1978.

[25] S. Myrvold, L. M. Reimer, D. L. Pompliano, and J. W. Frost, "Chemical inhibition of dehydroquinate synthase," Journal of the American Chemical Society, vol. 111, no. 5, pp. 1861-1866, 1989.

[26] N. Nikolaides and B. Ganem, "Design and synthesis of substrate analogs for the inhibition of dehydroquinate synthase," Tetrahedron Letters, vol. 30, no. 12, pp. 1461-1464, 1989.

[27] G. Fiala and K. O. Stetter, "Pyrococcus furiosus sp. nov. represents a novel genus of marine heterotrophic archaebacteria growing optimally at $100^{\circ} \mathrm{C}$," Archives of Microbiology, vol. 145, no. 1 , pp. 56-61, 1986.

[28] S. Tabor and C. C. Richardson, "A bacteriophage T7 RNA polymerase/promoter system for controlled exclusive expression of specific genes," Proceedings of the National Academy of 
Sciences of the United States of America, vol. 82, no. 4, pp. 10741078, 1985.

[29] L. R. Schofield, B. F. Anderson, M. L. Patchett, G. E. Norris, G. B. Jameson, and E. J. Parker, "Substrate ambiguity and crystal structure of Pyrococcus furiosus 3-deoxy-Darabino-heptulosonate-7-phosphate synthase: an ancestral 3deoxyald-2-ulosonate-phosphate synthase?" Biochemistry, vol. 44, no. 36, pp. 11950-11962, 2005.

[30] P. A. Lanzetta, L. J. Alvarez, P. S. Reinach, and O. A. Candia, "An improved assay for nanomole amounts of inorganic phosphate," Analytical Biochemistry, vol. 100, no. 1, pp. 95-97, 1979.

[31] H. H. Hess and J. E. Derr, "Assay of inorganic and organic phosphorus in the 0.1-5 nanomole range," Analytical Biochemistry, vol. 63, no. 2, pp. 607-613, 1975.

[32] F. H. Niesen, H. Berglund, and M. Vedadi, "The use of differential scanning fluorimetry to detect ligand interactions that promote protein stability," Nature Protocols, vol. 2, no. 9, pp. 2212-2221, 2007.

[33] M. M. Bradford, "A rapid and sensitive method for the quantitation of microgram quantities of protein utilizing the principle of protein dye binding," Analytical Biochemistry, vol. 72, no. 1-2, pp. 248-254, 1976.

[34] S. E. Bondos and A. Bicknell, "Detection and prevention of protein aggregation before, during, and after purification," Analytical Biochemistry, vol. 316, no. 2, pp. 223-231, 2003.

[35] J. R. Knowles, "Mechanistic ingenuity in enzyme catalysis: dehydroquinate synthase," Aldrichimica Acta, vol. 22, pp. 5966, 1989.

[36] D. L. Pompliano, L. M. Reimer, S. Myrvold, and J. W. Frost, "Probing lethal metabolic perturbations in plants with chemical inhibition of dehydroquinate synthase," Journal of the American Chemical Society, vol. 111, no. 5, pp. 1866-1871, 1989.

[37] W. R. Simpson, "A critical review of cadmium in the marine environment," Progress in Oceanography, vol. 10, no. 1, pp. 170, 1981.

[38] J. Llanos, C. Capasso, E. Parisi, D. Prieur, and C. Jeanthon, "Susceptibility to heavy metals and cadmium accumulation in aerobic and anaerobic thermophilic microorganisms isolated from deep-sea hydrothermal vents," Current Microbiology, vol. 41, no. 3, pp. 201-205, 2000. 

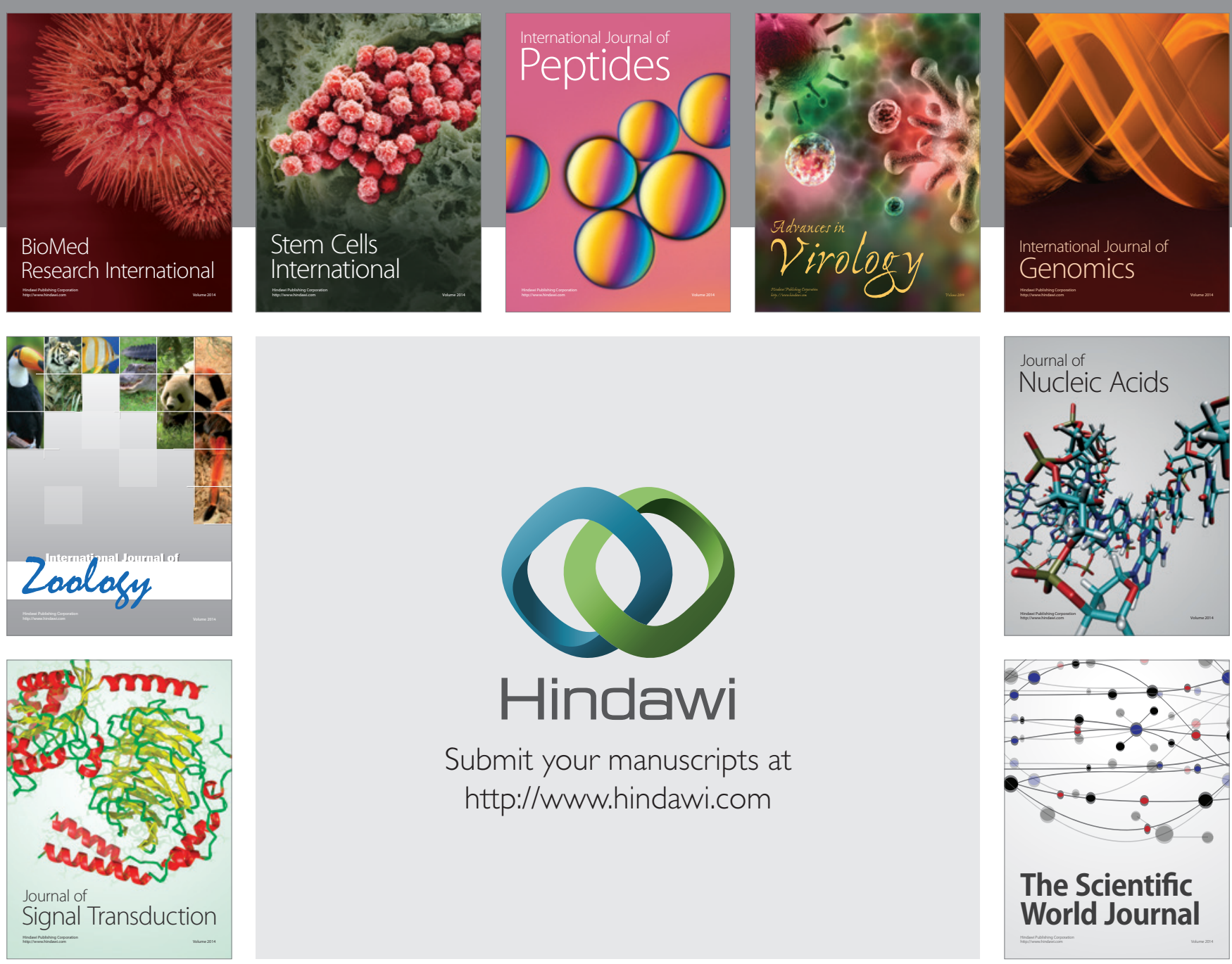

Submit your manuscripts at

http://www.hindawi.com
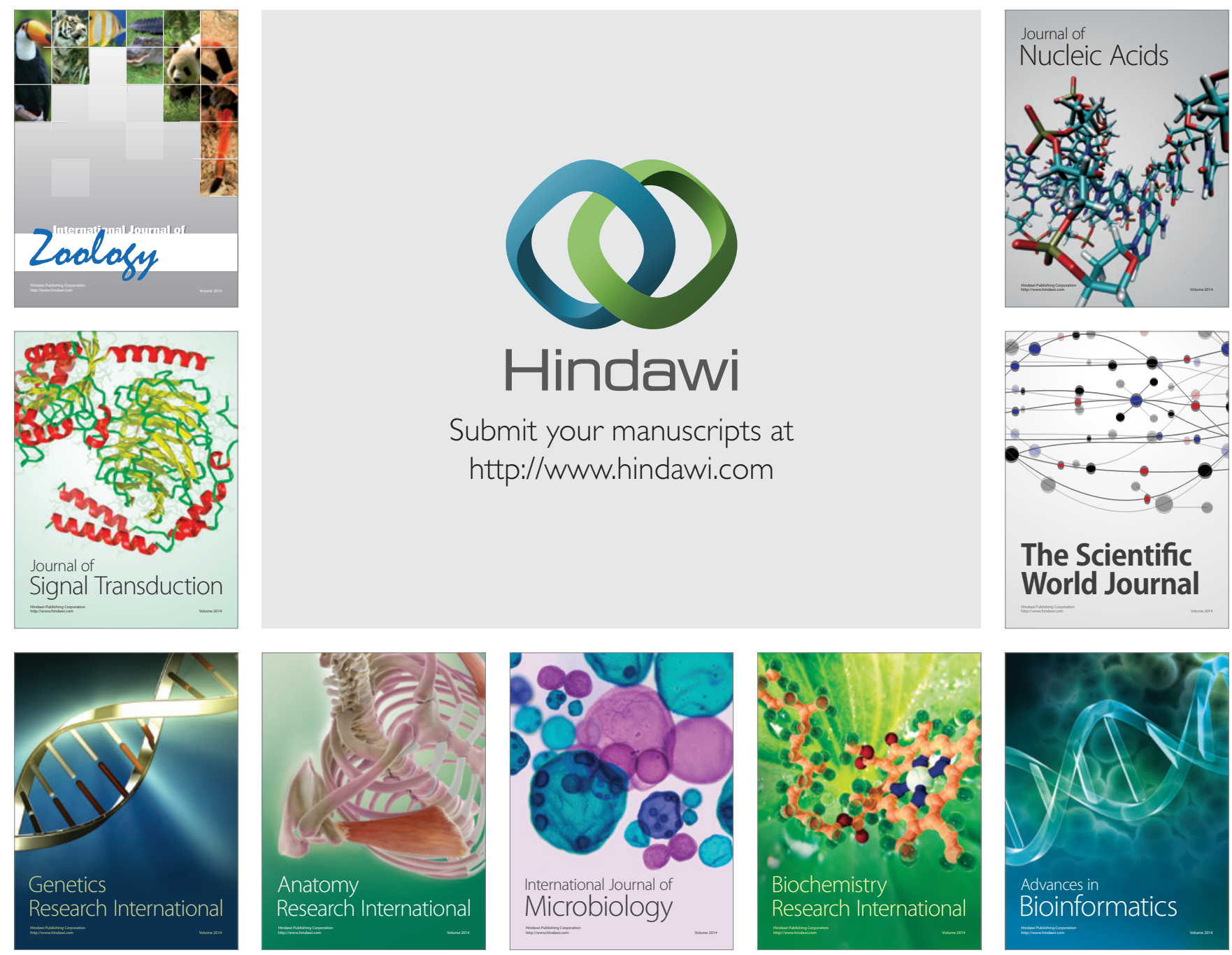

The Scientific World Journal
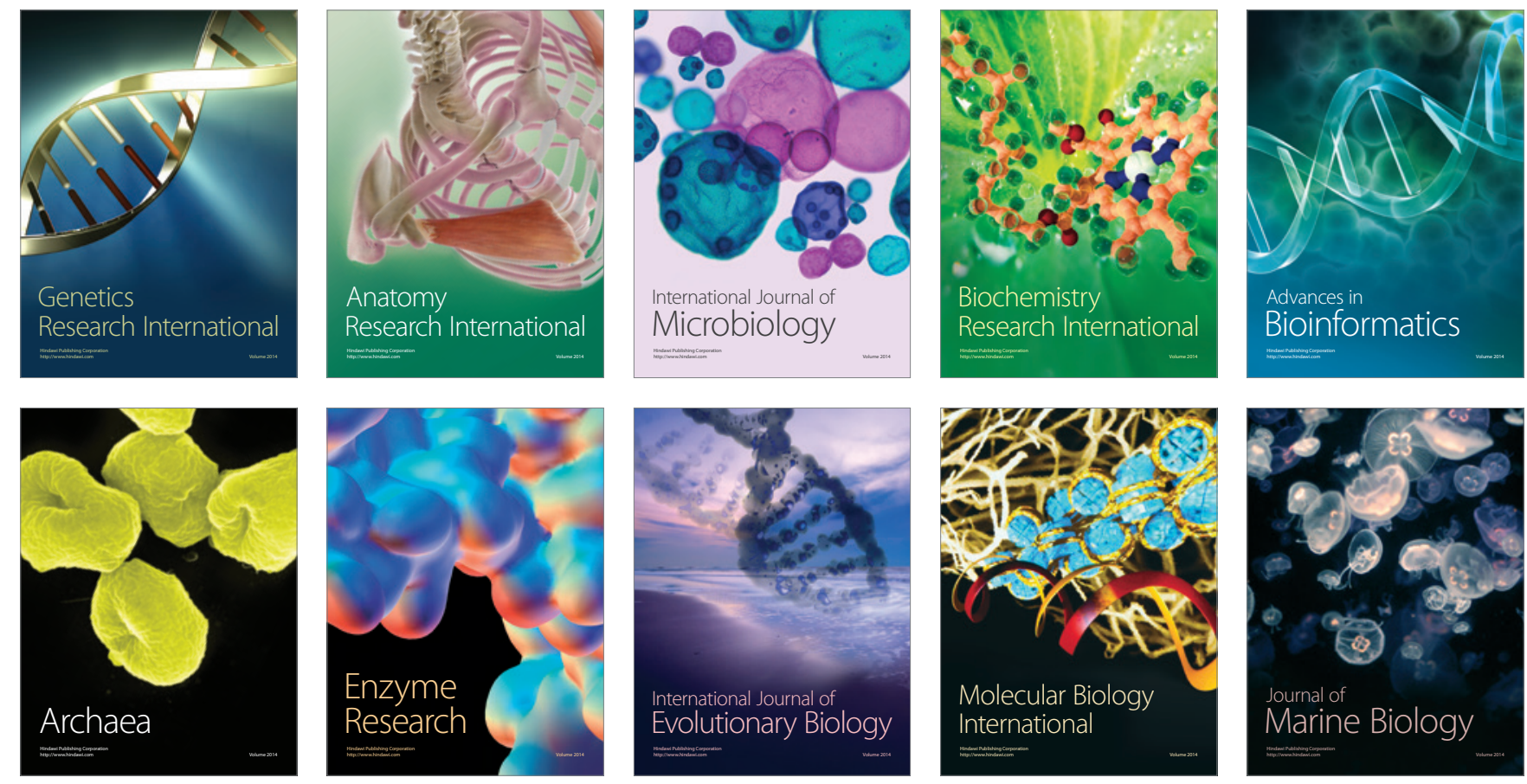